\title{
TOWARDS SUSTAINABLE TRANSIT ORIENTED DEVELOPMENT (TOD) IN DUHOK CITY - SHANDUKHA VILLAGE (NEIGHBORHOOD) AS CASE STUDY
}

\author{
SAdo Haji HAMO and MAHa J. Malaika* \\ Dept. Of Spatial Planning, University of Duhok, Kurdistan Region-Iraq
}

(Received: November 6, 2017; Accepted for Publication: February, 22, 2018)

\begin{abstract}
A Transit Oriented Development is an urban development style that supports compactness instead of sprawl, mixed land use, using public transportation as a main source of travel, providing pedestrian paths for walkability. Calthorpe (1993). The researchers selected Shandukha village (neighborhood) in Duhok cityKurdistan Iraq, as case study for this research. The study highlights negative impact of sprawl use on land in Duhok city that leads to emerging informal houses and consuming the agriculture land via changing into sprawl residential use, then mitigating future generation needs of land. Different applications of TOD in American and European cities were studied to figure out the outcome of TOD application and how it served these areas. Both qualitative and quantitative methods of data collection were used, involving site observation, interviews with local and international people, GIS and photographs for study area. For determining both variables of the study, the researchers selected the main hypothesis as "Cities with TOD style in growth are more sustainable than cities with sprawl style of growth". gathered data from local and international surveys was analyzed by GIS, SOWT, and Excel. Finally according to analysis and findings the researchers concluded the answers to research questions with some recommendations to develop land use in Duhok city neighborhood.
\end{abstract}

KEY WORDS: Transit oriented Development ( TOD), Urban Sprawl, Walkability

\section{INTRODUCTION}

I ncreasing number of cities worldwide are facing challenges of rapid urbanization, as well as increasing of low-density, separated-use development and growing up time of transit, leading to urban sprawl. A recent report released by UN- Habitat in 2016 shows the global pattern of cities with urbanization between 1995- 2015. See figure (1). Effects of rapid urbanization are urgently leading to follow more effective and innovative approaches such as; Transit-Oriented
Development (TOD), which have been rapidly developed and considered as one of the common urban planning patterns over the world especially in the United States. TOD looks widely on centrally placed general population transportation framework encompassed by generally highdensity business and settlement improvement. As explained by (Cervero, \& Bernick 1997) this system could support improving the quality of life in urban areas; which encourages high density of population, more livable spaces within mixed-use built environment.

*E-mail: Maha.jamel@uod.ac 


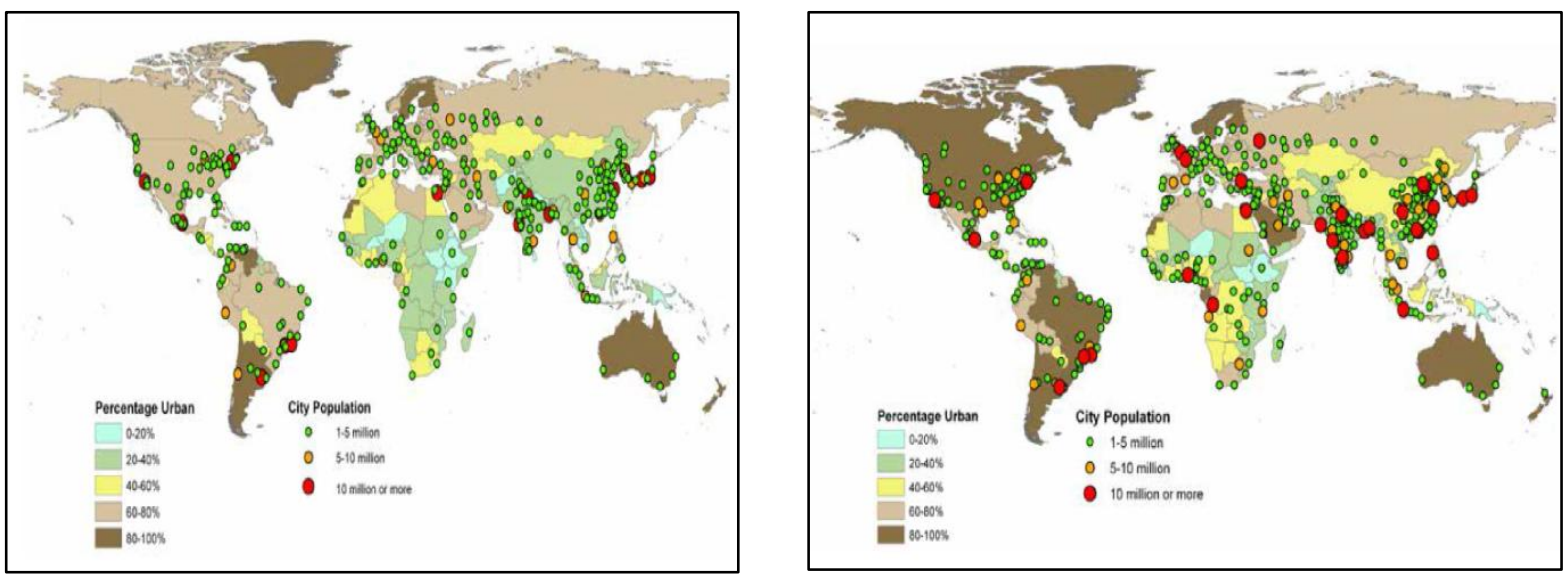

Fig. (1): Patterns of Global Urbanization 1995 \& 2015

\subsection{Background of the Study Problem;}

Duhok city is experiencing rapid assaulted urbanization. Duhok city is located geographically in a mountainous area bordered from north by Bekher Mountain and from south by Zawa Mountain. This situation creates limited land availability for urban growth of the city. The only opportunities for growth are from East and West. For example, Masiki quarter is located in the north-west of the city, with area around $6 \mathrm{~km}^{2}$ about 600 hectares, and population size in 2004 about1,000 inhabitants, while in 2010 it became about 15,000 inhabitants, This means more than 600 hectares of agriculture land have been occupied during 6 years.

(Directorate of statistics in Duhok city, 2010). Figures 2,3,4 below clears the situation of rapid urbanization and sprawl use of land around edges of

Duhok

city.

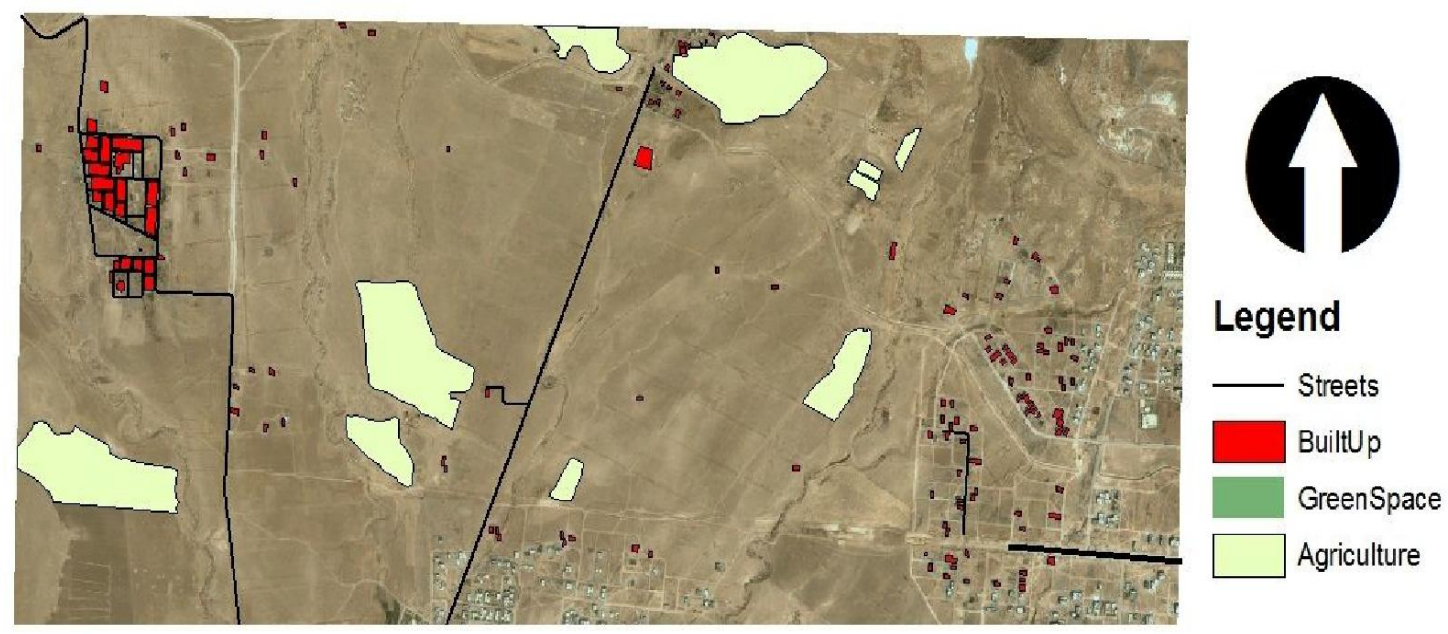



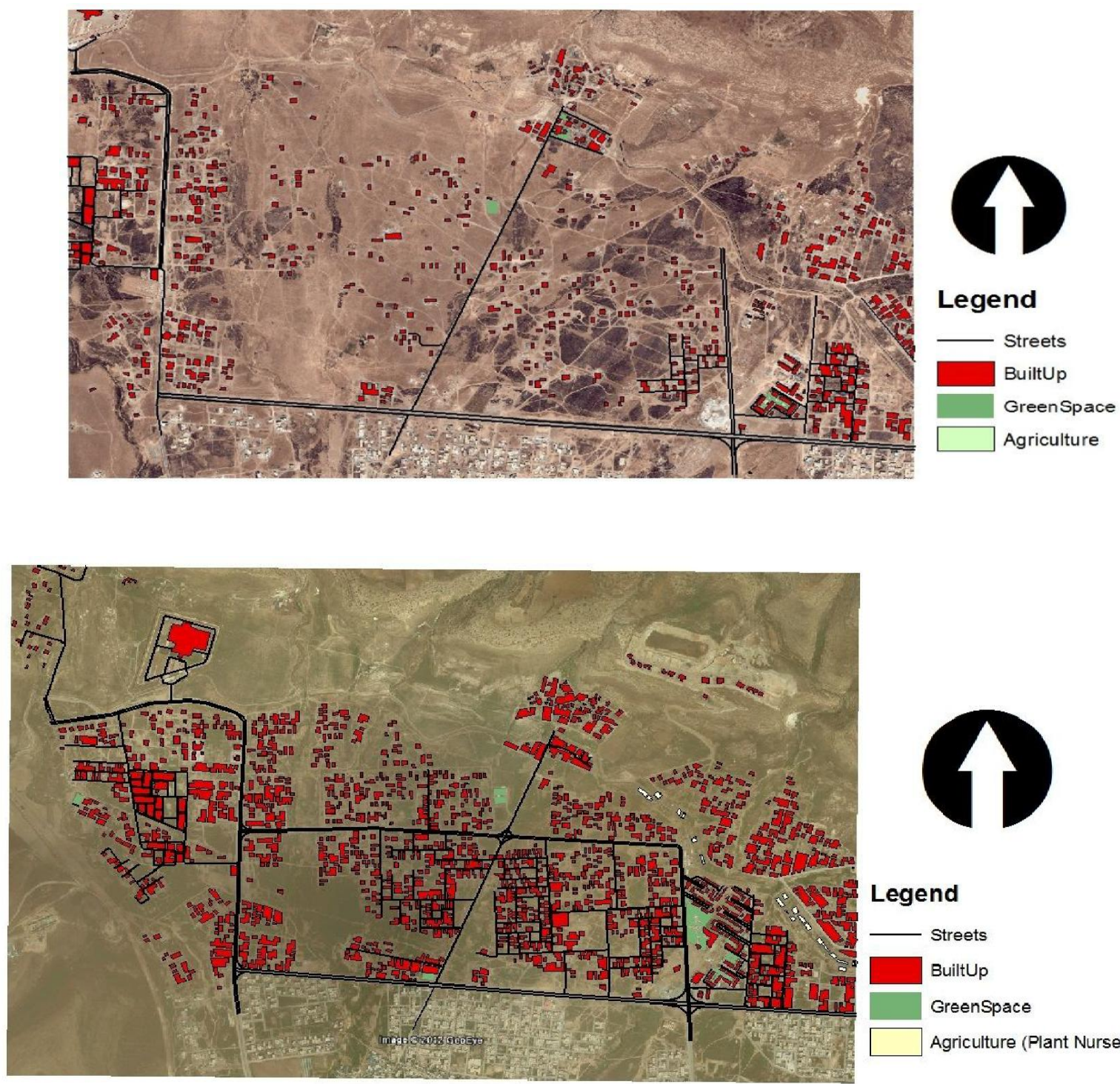

\section{Legend}

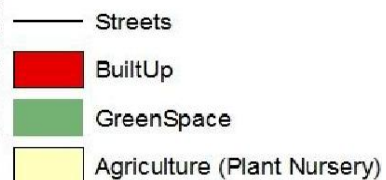

After Duhok city faced many infrastructural problems, and uncontrolled urbanization, in 2009 a Master Plan was provide for Duhok city to overcome the urban sprawl, but unfortunately the Master Plan has not been correctly applied due to the economic crisis. (Lina Eklund 2012 and Waheeda 2012). The rapid urbanization in Duhok city led to very fast demographic and infrastructure changes. In 2010 the government with German experts adapted a new master plan to guide the city till 2032. According to the master plan and Duhok's growth rate, built up area and population size will be almost double in target year (2032). (Expectations of directorate of statistics in Duhok (2016)). See figures 6,7. 


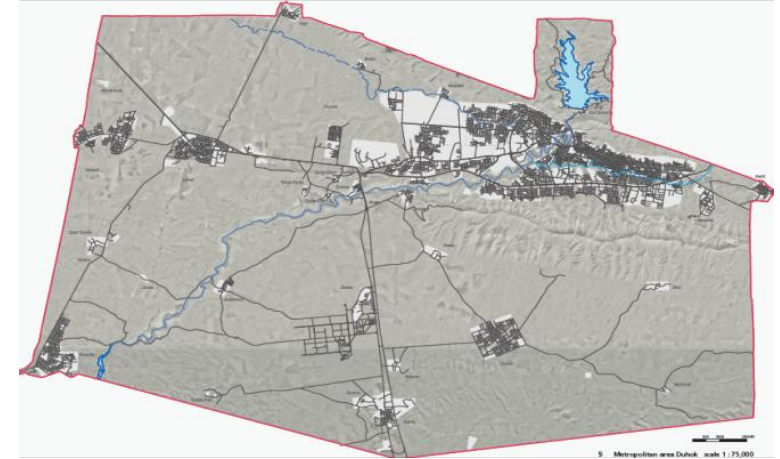

Fig.(6): shows Duhok city in 2010

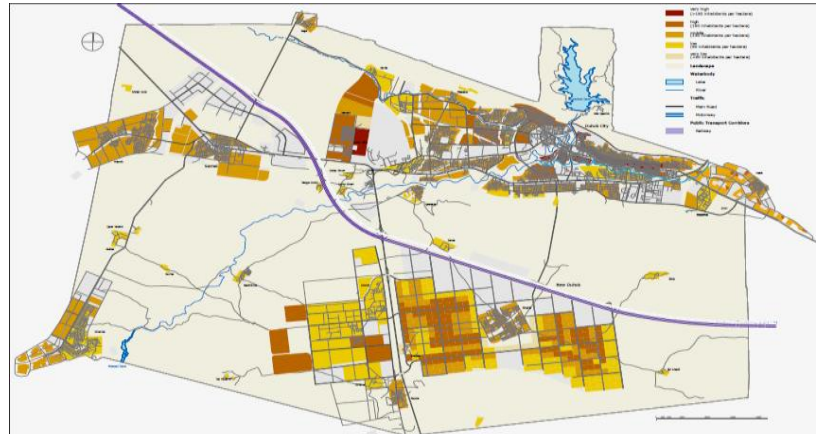

Fig.(7): Duhok master plan in 2032

Source: directorate of municipalities - master plan of Duhok city 2010

\subsection{Problem Statement:}

The lack of a clear urban planning and development approach to control the rapid urbanization and urban sprawl in Duhok City urges to investigate new approaches to reduce effects of urban sprawl; however more than 1000 hectares of land have been built up around edges of city in sprawl manner during the last 14 years. (Directorate of statistics in Duhok city, 2010). Rapid urbanization in Duhok city is due to both internal and external migrations. The growth rate exceeded $3.5 \%$ per year in the city (Directorate of statistics in Duhok city, 2015). The research will investigate how can integrated urban planning by applying Transit Oriented Development improve life quality in Duhok Urban areas.

\section{TRANSIT ORIENTED DEVELOPMENT (TOD) DEFINITIONS}

There are several definitions of TOD, in view of distinctive perspectives as well as viewpoints. TOD is defined basically as a high-density region arranged inside strolling separation of a travel station (CTOD, 2013), with walkability, highdensity, and, mixed-use. Bernick with also Cervero (1997) defined TOD similarly as a high density range place, someplace where available daily needs for shopping, housing are reachable, and offer of employment is available within short distances, planned to walkability pedestrian paths, using public transportation, reducing travel by private cars. What distinguishes TOD is concerning design change for a utilitarian relationship identified with transit for urban activities. (Fastracks, 2008). Calthorpe (1993) characterized TOD as direct style for secondary denser housing, close by essential analytics of daily uses, jobs; retail, and services. More recently, TOD is centered with mixed-use developments during key concentrates along regional frameworks.

\subsection{Impact of TOD on the Land Use Factors;}

According to TOD, there are different factors a land use plan for urban environment needs to be taken into consideration. As shown in table 1.

Table (1): impact of TOD on the Land Use Factors;

\begin{tabular}{|c|c|c|}
\hline Terms & Meaning & explanation \\
\hline Density & $\begin{array}{l}\text { Residents or jobs per acre or hectare of } \\
\text { land. }\end{array}$ & $\begin{array}{l}\text { Increased density leads to decrease using of } \\
\text { vehicles travel. For example increase in urban } \\
\text { density by } 10 \% \text {, leads to decrease use of per capita } \\
\text { car motor travel by } 2 \text { - 3\%. }\end{array}$ \\
\hline Mixed use & $\begin{array}{l}\text { related to the level of mixed activities } \\
\text { within an area uses such as housing, } \\
\text { commercial, institutional. }\end{array}$ & $\begin{array}{l}\text { Increased Mixed use of land tends to decrease per } \\
\text { capita vehicle travel, with more alternative modes } \\
\text { use for transporting, }\end{array}$ \\
\hline Connectivity & $\begin{array}{l}\text { Walk able level roads is connected and } \\
\text { permit direct transit among travel stations. }\end{array}$ & $\begin{array}{l}\text { Enhanced connected streets leads to decrease car } \\
\text { travel within neighborhood, and increases walking \& } \\
\text { biking inside neighborhoods. }\end{array}$ \\
\hline Conditions of biking & Deals with quality \& quantity of paths and & Upgraded conditions of walking and cycling \\
\hline
\end{tabular}




\begin{tabular}{lll}
\hline and cycling & $\begin{array}{l}\text { lanes through across level and security of } \\
\text { pedestrians }\end{array}$ & $\begin{array}{l}\text { increases mass transit that can decrease } \\
\text { automobiles transit, }\end{array}$ \\
\hline $\begin{array}{l}\text { Parking supply \& } \\
\text { management }\end{array}$ & Number of car-parking spaces per acre or & $\begin{array}{l}\text { Reducing parking supply leads to higher costs of } \\
\text { parking pricing and significantly reduce travel by }\end{array}$ \\
& & \begin{tabular}{l} 
private cars, and uses of public transportation. \\
\hline
\end{tabular}
\end{tabular}

( Source: Litman, T. 2010 Land Use Impacts on Transport)

\section{1Application of TOD in USA / Florida- Gainesville;}

The Florida study was constant implementation of TOD in three main levels of planning; regional planning, urban planning and neighborhood planning. The implementation of TOD on neighborhood level, Gainesville, as the biggest city in Alachua province. It serves as the cultural, instructive and business center point for the north focal Florida district supplying metropolitan services consists of :
- Position zone: is 0.5 mile almost about 500 acres of land around travel station consist of travel center and transit neighborhood.

- Travel center: to start with quarter mile or over 125 acres of land around travel station.

- Travel time neighborhood: second quarter mile or 375 acres of land encompassing travel center.

- Supportive Area of Travel: offering on that one mile around travel station. See Fig. 8 and table 2 for system of TOD in Gainsville city of Florida,

USA.

Table (2): System of TOD in Gainesville City of Florida

\begin{tabular}{|c|c|}
\hline $\begin{array}{l}\text { System of transit } \\
\text { module }\end{array}$ & $\begin{array}{l}\text { Bus station provided with busses } \\
\text { schedule give premium travel to } \\
\text { the passenger and administration } \\
\text { with respect to existing roadways } \\
\text { or clinched alongside committed } \\
\text { rights-of-way, and facilitating } \\
\text { travel time should be viewed for } \\
\text { TOD. }\end{array}$ \\
\hline $\begin{array}{l}\text { Functioning } \\
\text { speediness }\end{array}$ & $15-20 \mathrm{mph}$ \\
\hline Station Category & Walkway Sign, Platforms \\
\hline $\begin{array}{l}\text { Station } \\
\text { Arrangement }\end{array}$ & $\begin{array}{l}\text { Limited of bus stops along the buses } \\
\text { paths }\end{array}$ \\
\hline Facility Regularity & $\begin{array}{l}21 \text { to } 30 \text { minutes as maximum with } \\
\text { more than three bus routes as an } \\
\text { opportunity for travel }\end{array}$ \\
\hline Vehicle Length & $30-50$ feet \\
\hline
\end{tabular}




\begin{tabular}{ll}
\hline Alignment & $\begin{array}{l}\text { In road on traffic flow; could require } \\
\text { travel signal or extra involvements. }\end{array}$ \\
\hline
\end{tabular}

Source of table: Florida Department of Transportation 2012.

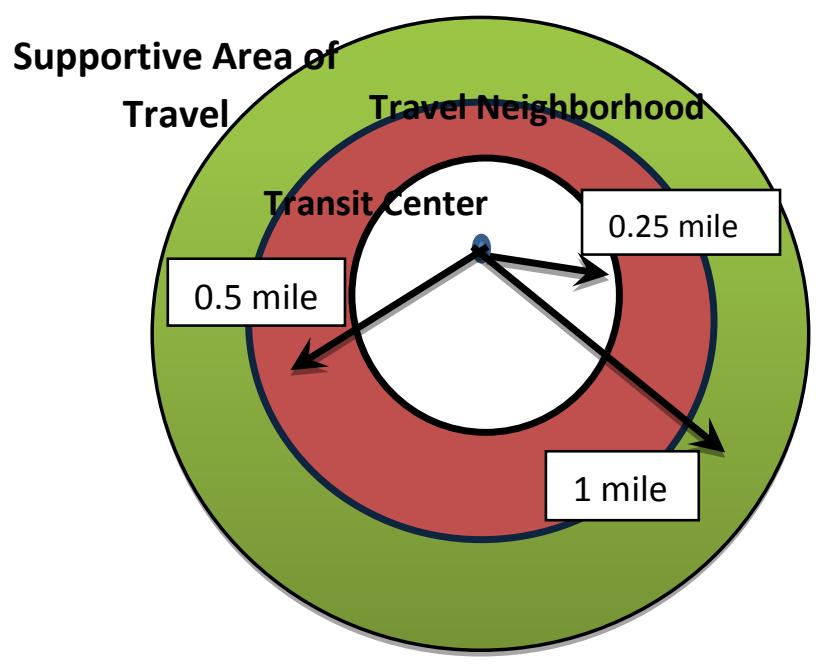

Fig. (8): TOD system in Gainesville;

Source: (Framework for TOD in Florida -March 2011

\subsection{Application of TOD in Europe, Germany, Freiburg, the Rieselfeld, and Vauban;}

It is a one of Germany's greenest city with notable and historic Freiberg's university town about reasonable urbanism and fringe redevelopment destinations connected to vital Freiburg by means of the region's tramway system (Figures 10,11), Freiburg is turning into a "City of short Distances," with "traffic avoidance,"

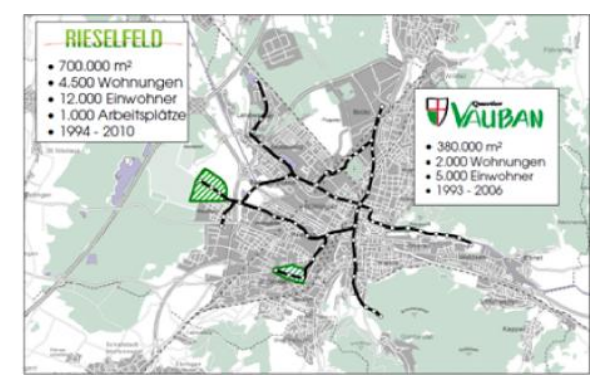

which is refined through mixture land utilization examples also near-ubiquitous general population travel. Rieselfeld and Vauban keep Freiburg's mandatory low-energy building standard from claiming $65 \mathrm{kWh} / \mathrm{m} 2$ /year (twice as productive Likewise Germany's national vitality standard). Providing plentiful green space, parks and playgrounds, cycling. and purify run-off through bio swales and different dirt filtration frameworks.

Fig. (10, 11): illustration maps of Rieselfeld and Vauban Districts;

Source: Robert Cervero and Cathleen Sullivan Toward Green TODs , p18

\subsection{Discussion of different international experiences of TOD}

The researchers discussed the argument of authors and application of TOD worldwide.

1- In comparison between Europeans and American patterns for urban development, we can imagine that American styles of TOD, could be more applicable in Duhok city, due to the

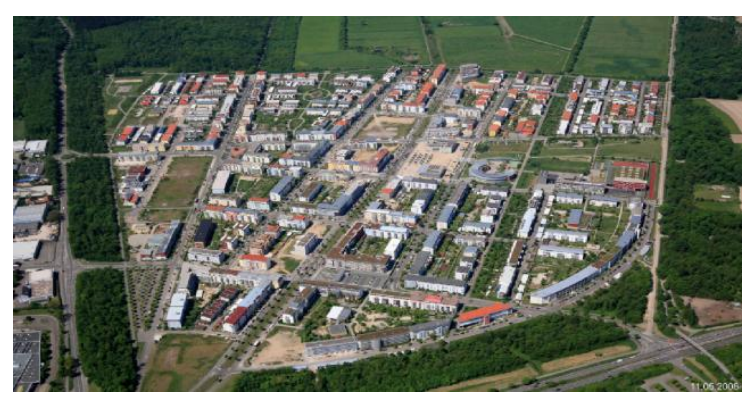


3- Those global considerations provide guidelines for environmental protection and reduce the utilization of resources such as converting natural environment into the built up area by sprawl infrastructure.

4- The researchers seek for local creation and institutionalization for reasonable approaches adopted justifiable for public benefits, and new styles of urban development, as part of Duhok's consideration in future urban management.

5- The researchers can define TOD as " A Style that encourages public transportation integrated with mix land use, with applicable character of regular urban growth, and emphasis on walkability, in local urban environment."

Accordinly the researchers concluded some main planning indicators that refer to TOD application in urban areas, to be tested in case study area.

1. Density 2. Mixture of Uses 3. Connectivity 4. Conditions of biking cycling and, Walkability

5. Open spaces supply \& management 6. Mass Transport.

\section{METHODOLOGY}

Table (3): Questions based on study indicators and distribution of variables

\begin{tabular}{|c|c|c|c|}
\hline \multirow{5}{*}{$\begin{array}{l}\text { Density use of } \\
\text { land }\end{array}$} & Xn.. & & Strongly agree, .....strongly \\
\hline & $\mathrm{X} 1$ & $\begin{array}{l}\text { High density use of land saves a land for future } \\
\text { generations }\end{array}$ & \\
\hline & $\mathrm{x} 2$ & Compact neighborhoods are more secure & \\
\hline & $\mathrm{X} 3$ & $\begin{array}{l}\text { Compact neighborhood are more sustainable } \\
\text { than sprawl neighborhood }\end{array}$ & \\
\hline & $\mathrm{X} 4$ & $\begin{array}{l}\text { Sprawl use lead to destroy } \\
\text { environment(changing green area and } \\
\text { agriculture area in to concrete or built up area ) }\end{array}$ & \\
\hline \multirow[t]{3}{*}{$\begin{array}{l}\text { Mixed use of } \\
\text { land }\end{array}$} & $\mathrm{X} 5$ & $\begin{array}{l}\text { Mixed use can provide daily needs within } 5 \\
\text { minute walks }(500 \mathrm{~m})\end{array}$ & \\
\hline & $\mathrm{X} 6$ & $\begin{array}{l}\text { Mixed use may provide different job } \\
\text { opportunities in same area or neighborhood }\end{array}$ & \\
\hline & $\mathrm{X} 7$ & $\begin{array}{l}\text { Using mix services in same neighborhood can } \\
\text { effect negatively on social structure of that area }\end{array}$ & \\
\hline \multirow{5}{*}{$\begin{array}{l}\text { Connectivity and } \\
\text { walking }\end{array}$} & & & Always....never \\
\hline & $\mathrm{x} 8$ & $\begin{array}{l}\text { Connective affordable pedestrian paths } \\
\text { encourage walkability }\end{array}$ & \\
\hline & $\mathrm{X9}$ & Using bus as travel mode & \\
\hline & $\mathrm{X} 10$ & - Using biking as travel mode & \\
\hline & $\mathrm{X} 11$ & - Using walking as travel mode & \\
\hline & & & Strongly agree.....strongly \\
\hline
\end{tabular}

The study included both qualitative and quantitative approaches for data collection and analysis, Including site visits, observations of the case study area. SWOT Analysis was also used for analysis. A Questioner of 75 forms consisted of 21 variables related to indicators chosen, as shown in table 3 was distributed to:

1- Local residents in Shandukha village (neighborhood)-Duhok as primary source of data collection, through distribution of 50 forms of questionnaire.

2- International people opinion included students and lecturers from University of Nebraska-Lincoln (UNL), since one of the researchers was living in Lincoln city -Nebraska-USA, during the time of questionnaire; he made use of this opportunity in conducting a questionnaire with lecturers and students in UNL to have their opinions of applying TOD in planning. 25 forms of questionnaires were distributed internationally, 20 students and 5 lecturers from University of Lincoln, Nebraska -USA. 


\begin{tabular}{|c|c|c|}
\hline \multirow{4}{*}{$\begin{array}{l}\text { Open space } \\
\text { supply and } \\
\text { management }\end{array}$} & \multicolumn{2}{|r|}{ disagree } \\
\hline & $\mathrm{X} 12$ & Green park should be within $500 \mathrm{~m}$ \\
\hline & $\mathrm{X} 13$ & $\begin{array}{l}\text { Streets within neighborhood need to be used be } \\
\text { people not for car parking }\end{array}$ \\
\hline & $\mathrm{X} 14$ & $\begin{array}{l}\text { Easier and more secure to park cars out of } \\
\text { streets }\end{array}$ \\
\hline \multirow{3}{*}{$\begin{array}{l}\text { Mass transit } \\
\text { (public } \\
\text { transportation }\end{array}$} & $\mathbf{X} 15$ & Transit station should exist within $500 \mathrm{~m}$ \\
\hline & $\mathrm{X} 16$ & $\begin{array}{l}\text { Public transportation provide more } \\
\text { economic and environment benefits }\end{array}$ \\
\hline & $\mathrm{X} 17$ & $\begin{array}{l}\text { Public transportation is more secure than } \\
\text { private transportation }\end{array}$ \\
\hline \multirow{4}{*}{$\begin{array}{l}\text { Interviewee } \\
\text { satisfaction of } \\
\text { TOD }\end{array}$} & $\mathrm{X} 18$ & $\begin{array}{l}\text { Using of TOD can overcome sprawl and } \\
\text { informal use of land in Shandukha village } \\
\text { (neighborhood) village }\end{array}$ \\
\hline & $\mathrm{X} 19$ & $\begin{array}{l}\text { TOD can provide sustainable environment to } \\
\text { case study }\end{array}$ \\
\hline & $\mathrm{X} 20$ & TOD tries to secure social needs \\
\hline & $\mathrm{X} 21$ & $\begin{array}{l}\text { TOD provides opportunity to save more } \\
\text { income, through using public modes of } \\
\text { transportation and walking }\end{array}$ \\
\hline
\end{tabular}

Research Hypothesis; "Cities with TOD style in growth are more sustainable than cities with sprawl style of growth".

\section{CASE STUDY AREA SHANDUKHA VILLAGE (NEIGHBORHOOD)}

Shandukha village (neighborhood) is located in the western-south side of Duhok city in North Kurdistan -Iraq. . Its elevation is $518 \mathrm{~m}$ above sea level; it lays on $\left(42.58^{\prime} 27^{\circ} \mathrm{E}, 36.56^{\prime} 56^{\circ} \mathrm{N}\right)$. The residential houses were built randomly without any planning or organizing. Its population size is about 4600 inhabitant in 2015, with 612 families, and 593 houses. (Statistical Office 2015) 


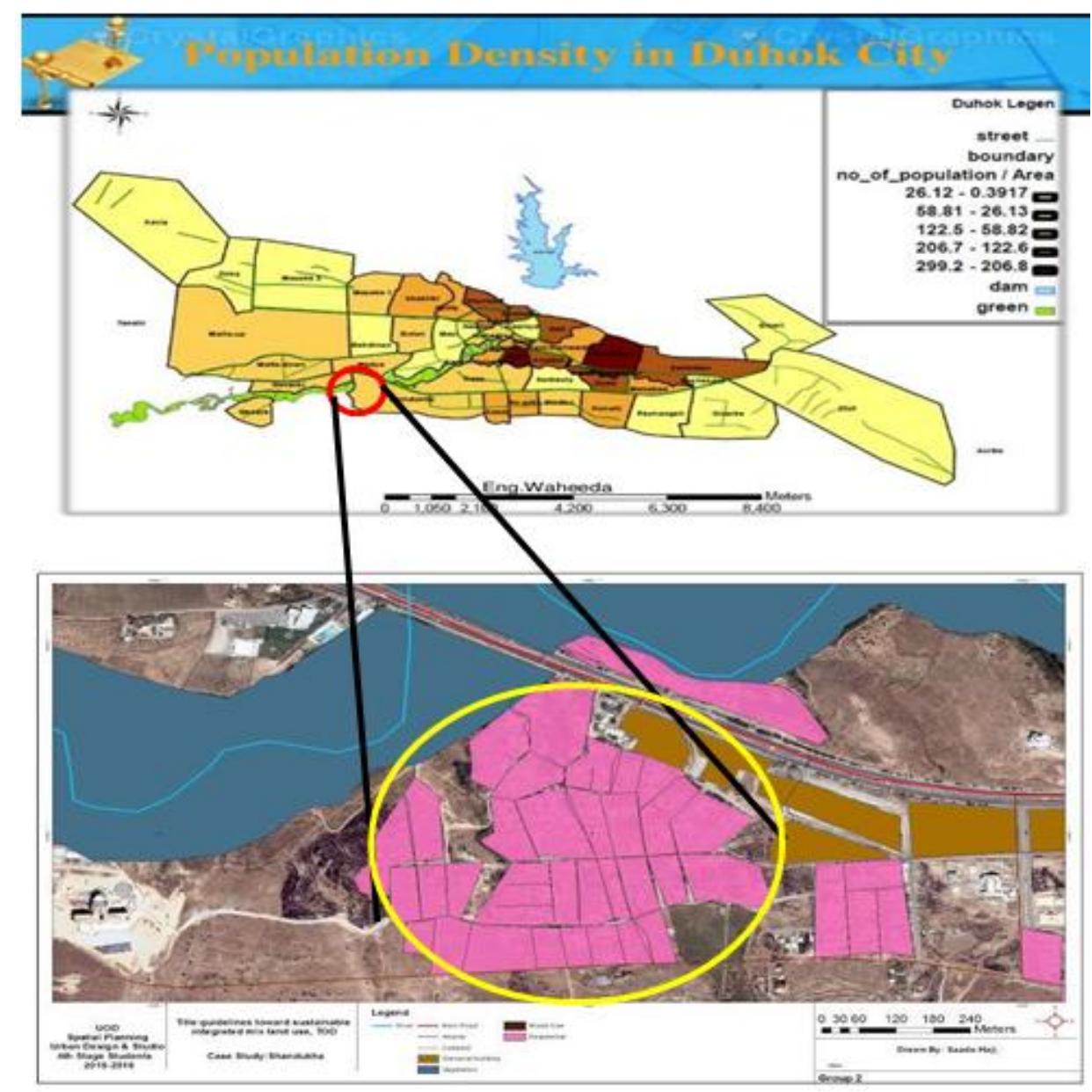

Fig. (12): the location of case study areas within Duhok city. Source; the researchers by GIS

The Name of Shandukha village (neighborhood) came from Assyrian king called " Alu-Su-Du-Xi", now known as Shandukha It was a city in 1800 B.C according to Sumerian texts which gives historical importance to the area. Nowadays it is one of Duhok's main neighborhoods, majority of residents are mediumclass and above. See figure 13. The local government warned people not to use the land for illegal sheep keeping; however some people were still using the land for farming and sheep keeping, so the sheep keeping places were destroyed officially in June 12, 2013. Main Barzan road was constructed in early 1980s. (Municipality of Duhok, 2015). Through site visits the researchers observed poor infrastructure that ensures Shandukha village (neighborhood) has been developed without any planning standards of urban growth, no pedestrian paths, or sewerage streams in streets, or open spaces. See figures $13,14,15,16$. 


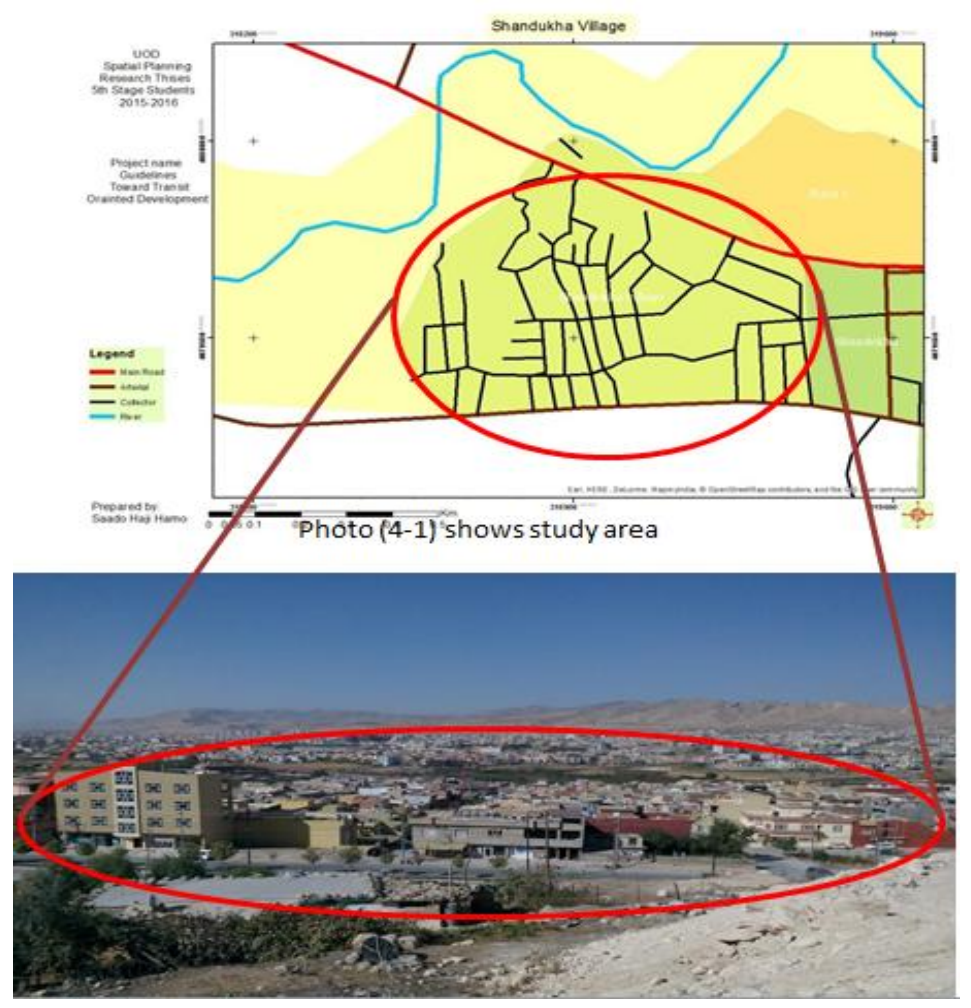

Fig. (13): Photo of case study and its map
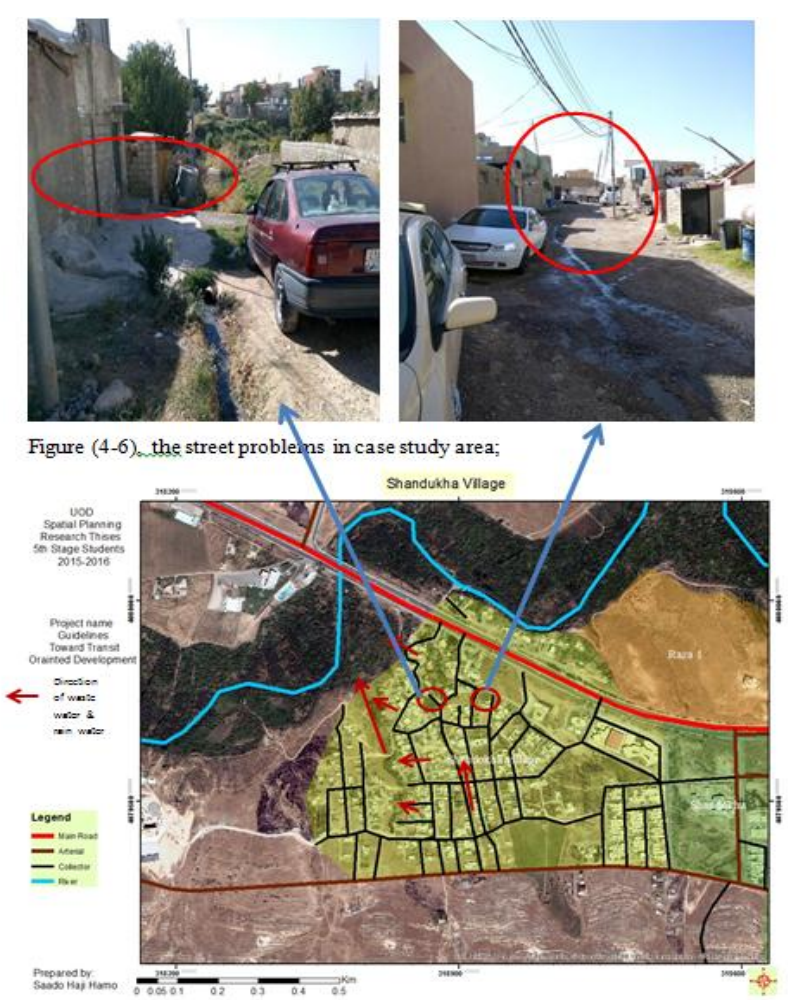

Fig. (14): Current situation of case study area in 2016 


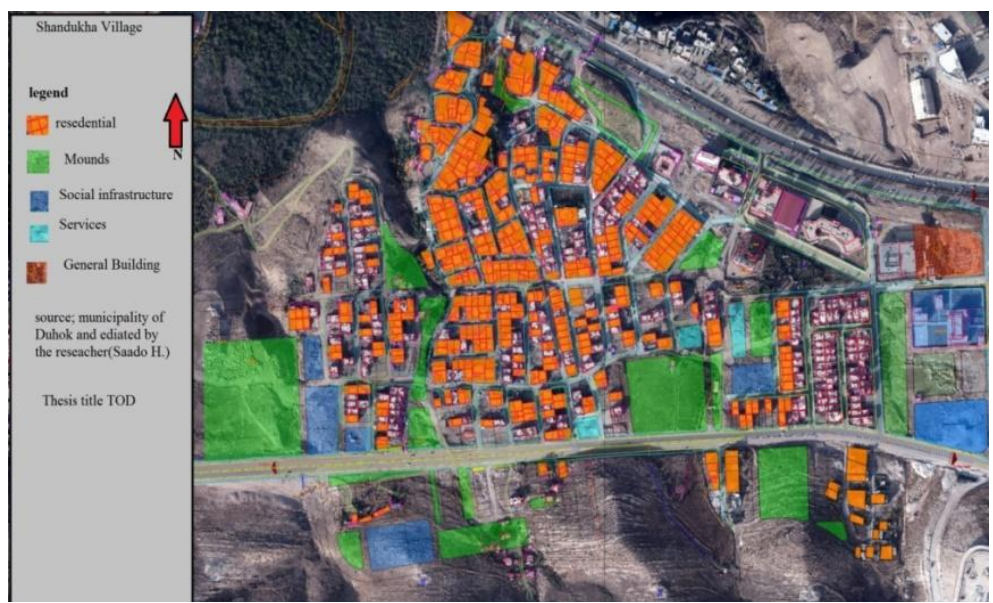

Fig. (15): streets and paths status in case study.

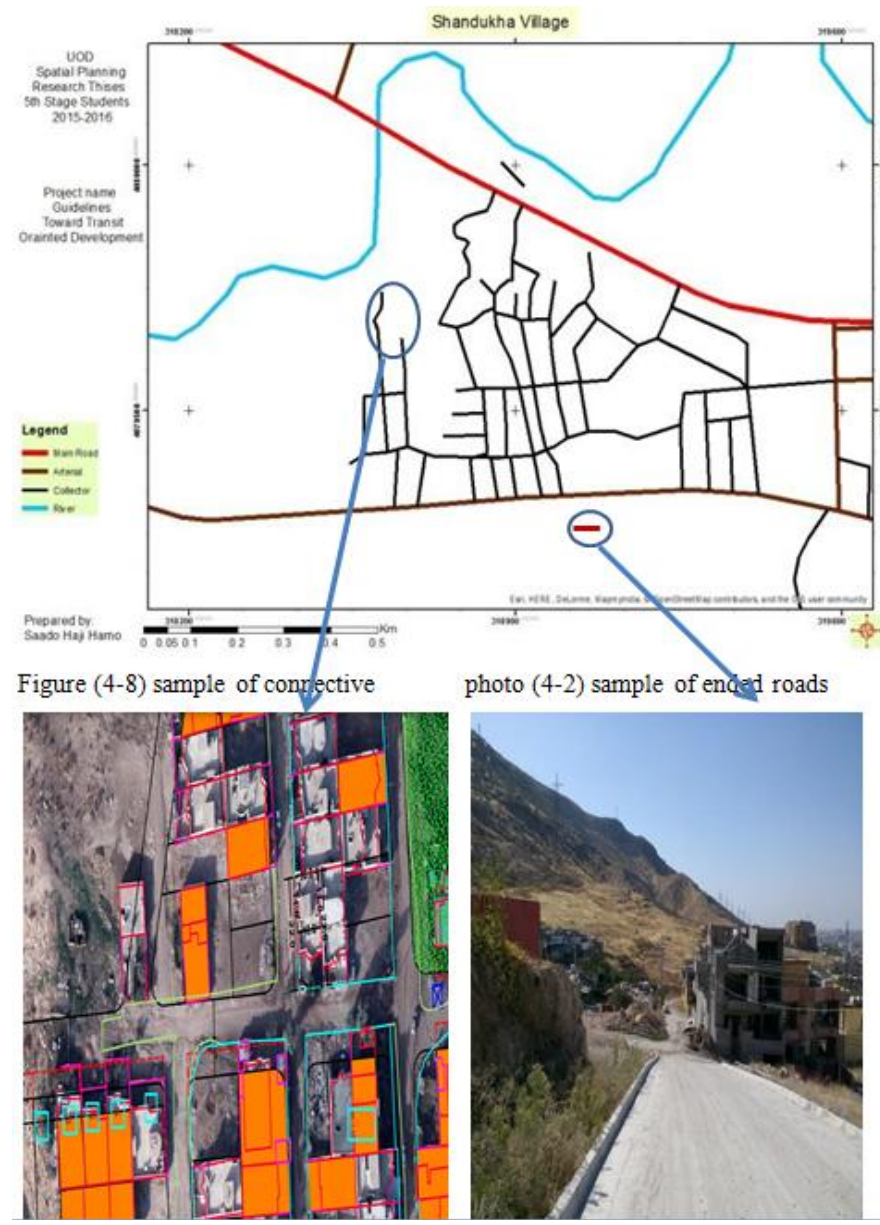

Fig. (16): connectivity and walkability situation in case study Source; researchers through site visit, edition of map by GIS.

-Current Mixed, and Density of land use in Shandukha village (neighborhood) Village;

During site visit and observation, simple mono landuse was found in case study area. Two primary schools, three nurseries, two kindergartens, one Mosque, three markets, two mini bus stations. 


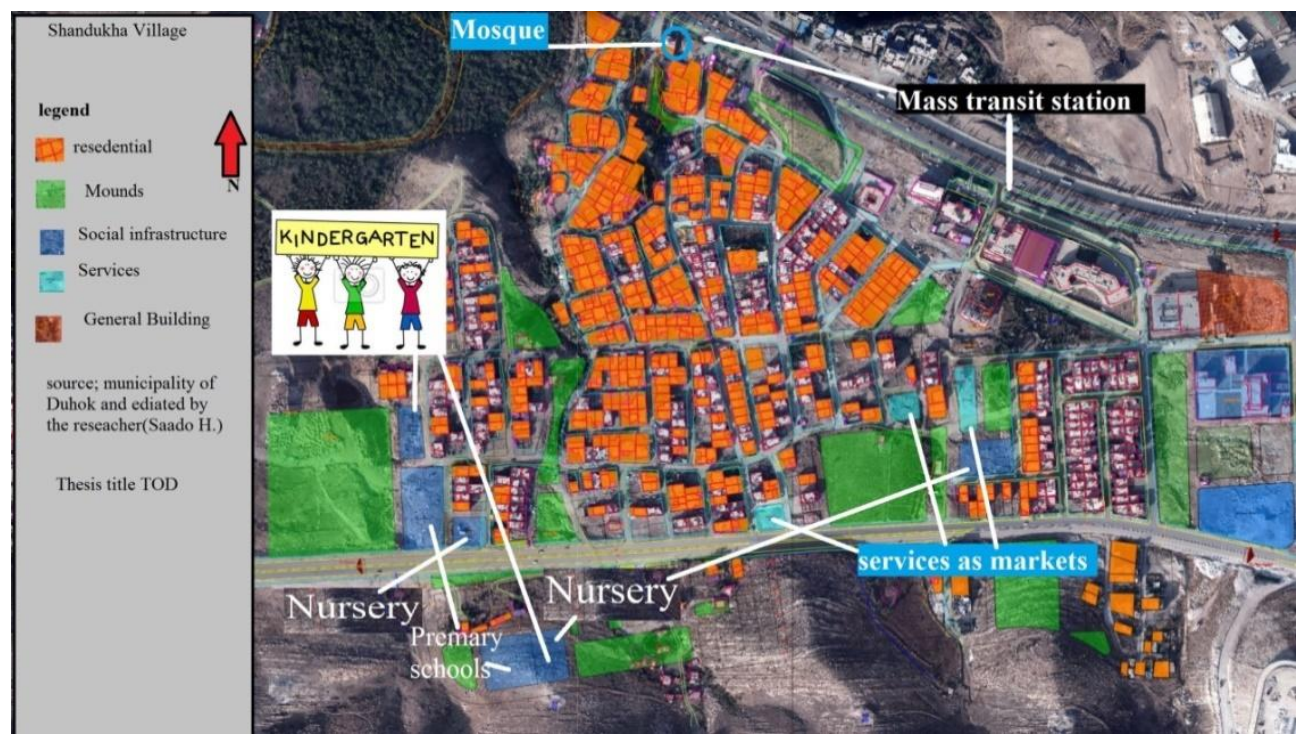

Fig. (17): current density and land use in case study area;

\subsection{SWOT Analysis of Appling TOD in Shandukha village (neighborhood);}

SWOT refers to Strengths, Weaknesses, Opportunities, and Threats results of analysis as follows in Table ( 4 ) SWOT Analysis

\begin{tabular}{|c|c|c|c|}
\hline & Economic & Social & Environment \\
\hline Strengths & $\begin{array}{l}\text { - Save income by using public } \\
\text { transportation for travel more than } 5 \\
\text { minutes walking, and walking for } 5 \text { minutes } \\
\text { or less. } \\
\text { - save the land through high density use. }\end{array}$ & $\begin{array}{l}\text { - Mixing services } \\
\text { leads to new jobs and } \\
\text { experiences. } \\
\text { - finding of social needs in } \\
\text { neighborhood }\end{array}$ & $\begin{array}{l}\text { - saving land means saving the } \\
\text { nature. } \\
\text { - using walking and public } \\
\text { transportation keeps the clean } \\
\text { environment. }\end{array}$ \\
\hline Weaknesses & $\begin{array}{l}\text { - currently, the local government is facing } \\
\text { economic crises. }\end{array}$ & $\begin{array}{l}\text { - conversion of community } \\
\text { from rural directly into } \\
\text { modern urban life }\end{array}$ & $\begin{array}{l}\text { - The nature of topography in case } \\
\text { study is mounds }\end{array}$ \\
\hline Opportunities & $\begin{array}{l}\text { - TOD can bring new job opportunities } \\
\text { through mixed use. } \\
\text { - TOD provides new modes of travel to } \\
\text { save income as mass travel and walking. }\end{array}$ & $\begin{array}{l}\text { - TOD can provide social } \\
\text { needs to people in } \\
\text { Shandukha. }\end{array}$ & $\begin{array}{l}\text { - TOD can solve the problem of } \\
\text { sprawl use of land in case study. }\end{array}$ \\
\hline Threats & $\begin{array}{l}\text { Continuing of urban sprawl demands more } \\
\text { infrastructure and services. }\end{array}$ & $\begin{array}{l}\text { Continuing of unsafe } \\
\text { pedestrian and sidewalks } \\
\text { in case study leads. }\end{array}$ & $\begin{array}{l}\text { - Continuing of urban sprawl leads } \\
\text { to destroy the nature and } \\
\text { agricultural }\end{array}$ \\
\hline
\end{tabular}

\section{DISCUSSION AND RESULTS}

The researchers analyzed and discussed the gathered data through questionnaire about applying planning indicators of TOD in Shandukha village as follows;

Density; Mixture of Uses; Development of short distance (Connectivity, Walkability and Biking); Mass Transport;

\section{1. Density;}

High density of Residence gives a suitable measure of saving land for future generation, easier and more economical to provide infrastructure. TOD obliges premium travel service, which is not attained by those low density areas and sprawl areas. Density of case study is about 75 P/Hct. (statistical office of Duhok 2016), which is an acceptable density of population per 
hectare according to TOD standard, about $65 \%$ of land of neighborhood is used for residential and only about $85 \%$ Shandukha village neighborhood is valid for use, other $15 \%$ is valleys and mounds not valid for use, with it $15 \%$ is used for streets within neighborhood, and $10 \%$ for social services. There is no land for recreational and other activities such as parks, cultural...etc.. In general about $70 \%$ of local people, $100 \%$ of lecturers and $65 \%$ of students agreed that high density use saves land for future generation and more sustainable than sprawl use of land.

\subsection{Mixture of land uses;}

Mixing of land use including mixing residential, office, retail marketing is necessary to support and encourage land reserve; then support livability of Shandukha village (neighborhood). From analysis of questionnaire $68 \%$ of local people, $100 \%$ of interviewed lecturers $90 \%$ of interviewed students approved that mixed land use can provide daily needs within five minute walk, and supply range of job opportunities.

Figure (14) shows there are no parks or open spaces, so residents have to travel far to enjoy open space, as there is no station of mass transit or green area within buffer of walking distance.

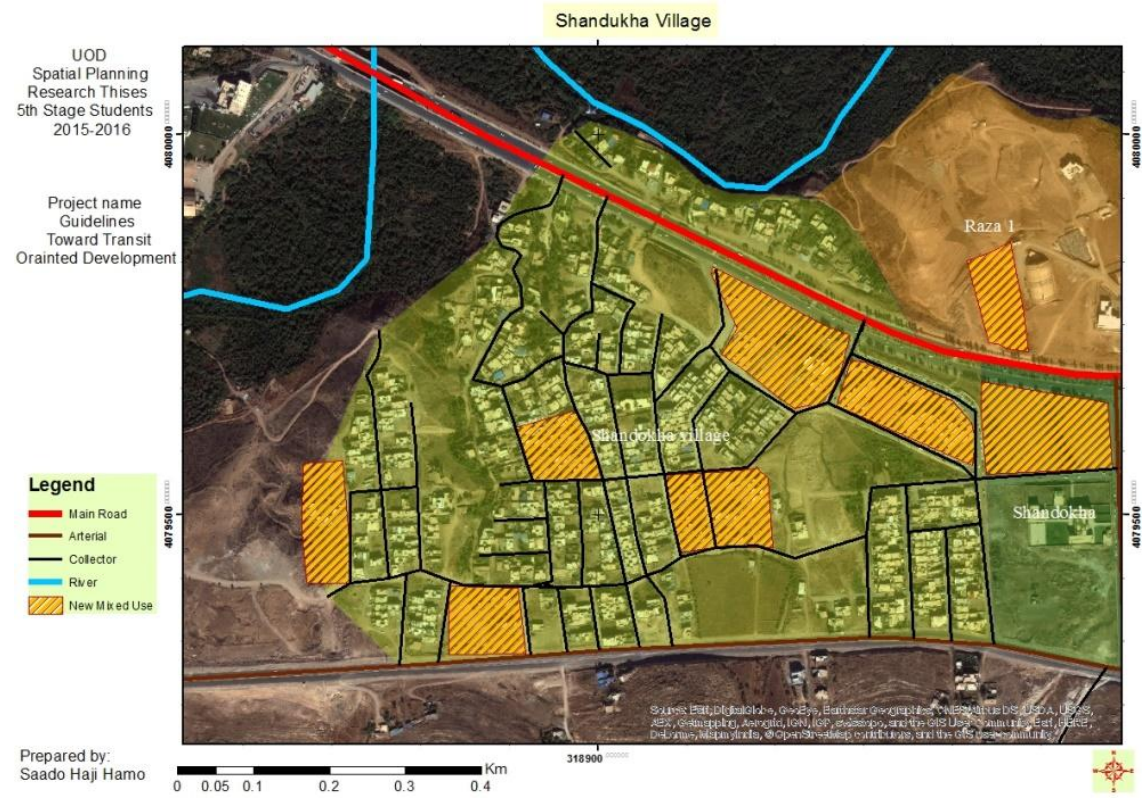

Fig. (14): current and opportunity of horizontal mixed land use in case study;

\subsubsection{Development of short distance (Connectivity, Walkability and Biking);}

Similarly as may be noted in literature and application of TOD, a key part of great TOD is walkability; however, from analysis the results of questionnaire is about $85 \%$ of interviewed studentss, $100 \%$ of interviewed lecturers and $80 \%$ of local people expressed the importance of affordable connective pedestrian paths to encourage walking. Table 6 compares both.

Table (6): Comparison between case study area and TOD Approach. Source: Researchers

\begin{tabular}{ll}
\hline Sprawl neighborhood (case study area) & Compacted and walkable neighborhood \\
\hline Less connectedness & Connectedness \\
Less walkability & Walkability \\
Less safety & More safety \\
Environment problem & Friendly with environment \\
Under developing neighborhood & Sustainable neighborhood \\
\hline
\end{tabular}




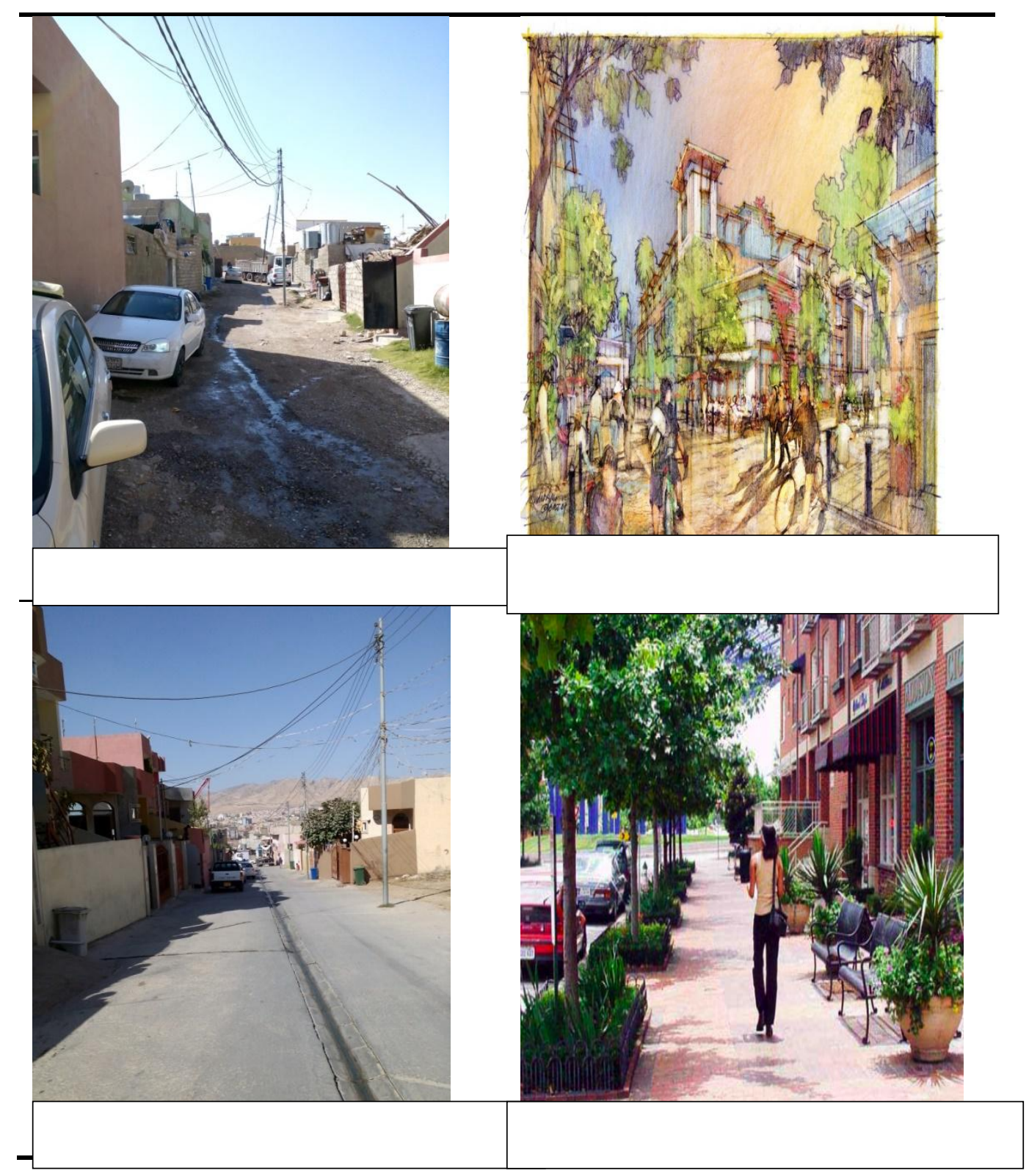

\subsubsection{Mass transit;}

Mass transit can be arranged through organized (time schedule and stations), encourage and supply basic needs of public transport such as buses and trains with affordable price in case study area, mass transit provides same right to all passengers. There are mini bus of 12 passengers are serving between Shandukha village and downtown of Duhok city with cost 500 Iraqi Dinar (ID) per passenger. Based on questionnaire results, $80 \%$ of Local people interviewed, $100 \%$ of interviewed lecturers, $85 \%$ of interviewed students expressed the need of public transport station within $500 \mathrm{~m}$ or 5 minute walk to serve the people, and also expressed that public transportation is more economic. Figures $(15,16)$ below show questioner results of students and lecturers satisfaction of TOD, as a suitable approach for development in study area. 


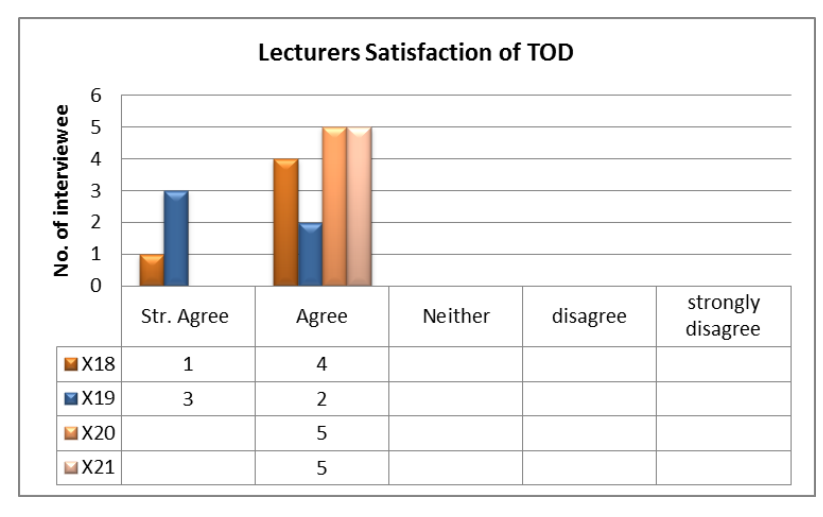

\subsection{Proving Hypothesis;}

From theory and practical study,interviews, questionere expectation about TOD, we can find $80 \%$ of Shandukha village (neighborhood), $100 \%$ of lecturers $90 \%$ of students answered agree and supported the ideas that TOD can overcome sprawl and informal use of land and housing, provide more sustainable environment to the urban areas, which proves the hypothesis: Cities with TOD style in growth are more sustainable than cities with sprawl style of growth.

\section{CONCLUSIONS}

\subsection{Conclusions related to theoretical part:}

The researchers specified main planning indicators to apply TOD and answering the research questions. Towards the different theories and experiences that are told by (Belzer, Eaton, Fogarty, \& Ohland, 2008). As well as people opinions, TOD can play important role of more compact and dense development pattern to reach sustainable development. Mixed land use provides diversity of houses and services with healthier, cleaner, and more affordable living choices, especially when compared with single use land. According to different surveys that held by Bernstein, 2004, p. 233, and U.S. Department of Transportation, 2008 , that for each $1 \%$ growth in metropolitan land use, annual Vehicle Miles Travel enlarged by at least $1.25 \% "$ ". So normally The number of vehicle miles traveled in a region directly affects congestion levels then environment, also the different surveys hold by researchers approved that TOD can supports urban environment. (Arrington \& Cervero, TCRP Report 128 Effects of TOD on housing, parking, and travel, 2008) clear that TOD residents are far less likely to commute to work by an automobile when reliable public transportation is easily accessible by a short walk or bike ride, effectively removing more automobiles from roadways. Fewer automobiles on roadways mean less pollution, cleaner air.

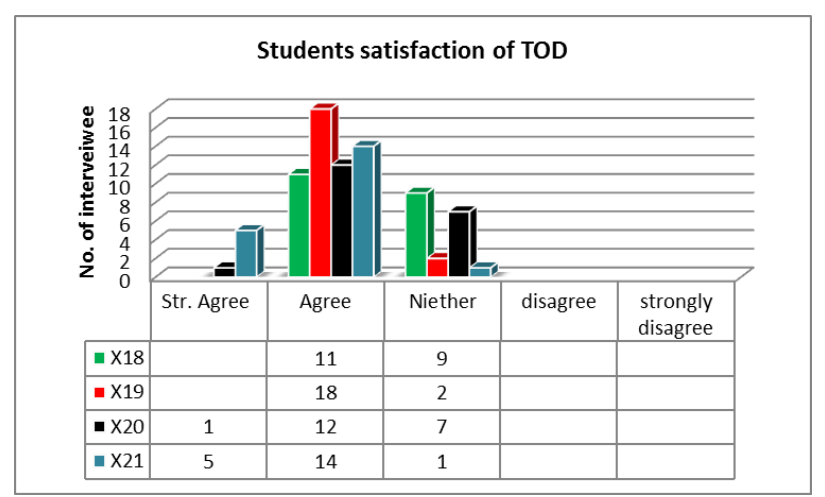

6.2 Conclusions related to Case study area:

A. There is a weakness of mixed land use both vertically and horizontally in Shandukha village leads local people to travel far to get daily need.

B. There is unplanned and scattered densities for both population and housing in the neighborhood. A need of new approach to overcome the sprawl use of land. Compact use and high density use can reduce informal housing of urban areas by saving land for future generation. This component of TOD is missing in case study area.

C. TOD approach can support providing infrastructure services such as sewerage, public transportation station, and social services, in less cost by concentrating services instead of providing infrastructure for far sprawled areas.

D. TOD neighborhoods are more safer than sprawled neighborhoods through providing

pedestrian paths for short distances of travel and providing near bus station for long distance of travel, non-motorized travel in both. Widening of streets within neighborhood is a negative point that encourage travel by motorized cars.

\section{RECOMMENDATIONS}

Applying Transit Oriented Development (TOD) is a suitable style and local level of urban development in Duhok city as well as for case study area to lessen the sprawl.

\section{-Short Term Plan in case study area:}

a. Recommending new circulation around case study area, by closing two roads that come from Barzan Street to Shandukha village

(neighborhood), and opening a road around the neighborhood to keep on privacy, stop through traffic in the main street of neighborhood. In the next phase to suggest a pedestrian area inside the circle area shown in figure (17),

b. Constructing bus station with fixed schedule beside case study area to support public transportation. as in figures 18. 


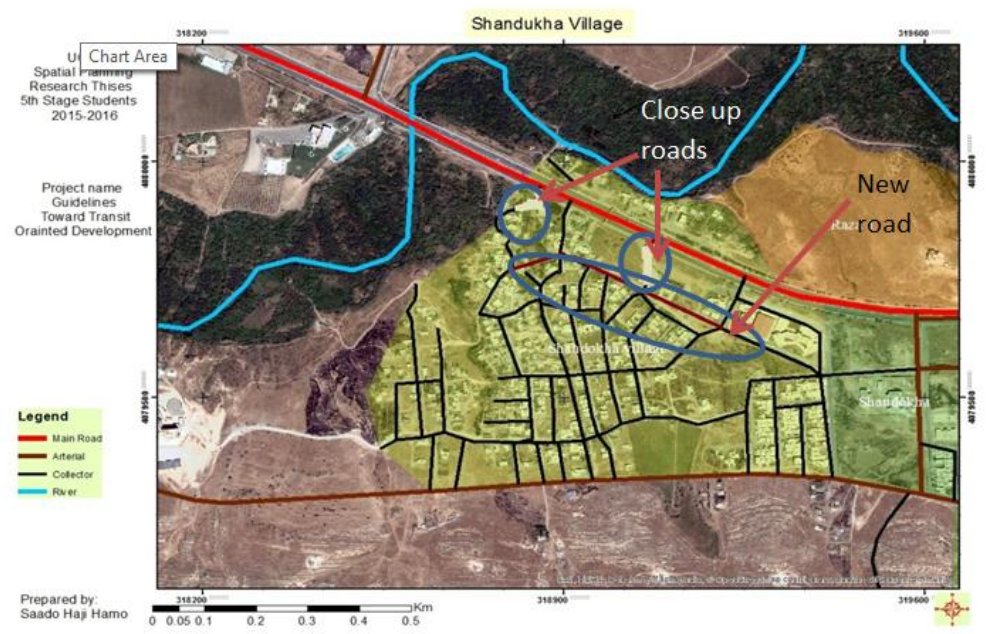

Fig. (17): opportunities of case study to develop travel.

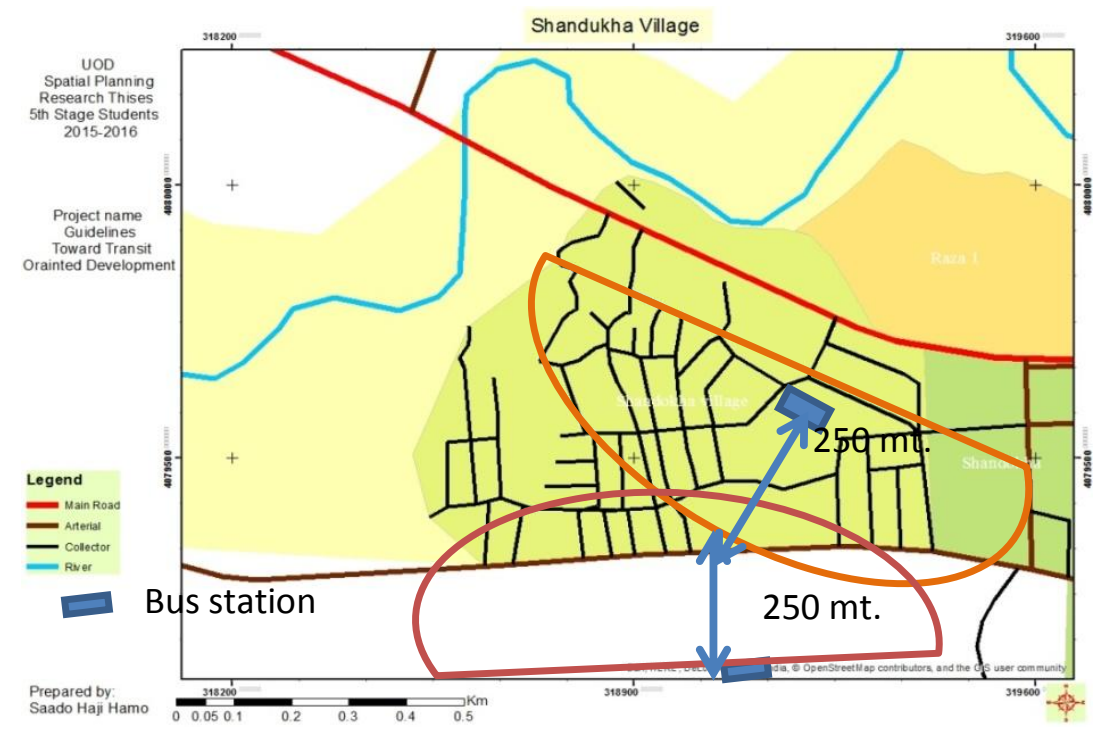

Fig. (18): Suggested Bus Stations

d. Reductions of motorized travel by requesting compact, mixed-use, and short distance development and providing daily needs within short distance in TOD development.

\section{- Long Term Plan in Duhok City:}

$\checkmark$ ong term plan for urban development to meet the complete components of Transit Oriented Development (TOD) in the whole Duhok city area, and neighborhoods including public transport stations, high densities, variety of housing and population densities, walkability, pedestrian and green connected networks and parks to achieve social, economic and environmental benefits for local people within sustainability.

\section{REFERENCES}

- Arrington, G.and Cervero, 2008. Vehicle Trip Reduction Impacts of Transit Oriented Housing. Journal of public transportation pdf, 11(3), page 1-17.

- Arrington, G., \& Cervero, R. (2008). TCRP Report 128 Effects of TOD on housing,parking, and travel. Transit Cooperative Research Program. Washington, D.C.: Transportation Research Board.

- Calthorpe.P,1993-1994. Next Metropolis of American: Ecosystem, Community,

Development of a framework for TOD. Pdf page 5,6 
-Colthorpe and Fulton, (2001) University of Washington, Planning for end of urban sprawl.

- Cervero, R. \& Bernick.M,1997. Transit Villages in the $21^{\text {st }}$ Century pdf. McgrawHill, Companies.page 8.

- CTOD, 2013. Center of Transit Oriented Development http://www.ctod.org/portal/. P 5, 6 pdf.

- David Dodman, Gordon McGranahan (2013) integrated of land use, USA pdf.

- Directorate of municipalities in Duhok city, master plan of Duhok city 2010, for urban development.

-Diane Q, March 2011 Framework for TOD in Florida pdf -Page 3, 5

-Florida Department of Transportation, 2012, transportation+of+Florida

$\&$ FORM $=$ HDRSC 2

Retrieved 2016 March 15.

-FasTracks. 2008. Strategic Plan for Transit Oriented Development, Regional Transportation District pdf.

-Hayden, D. (2004). A Field Guide to Sprawl. New York: W. W. Norton and Company. Intermodal Surface Transportation Efficiency Act. FHWA. https:// www.fhwa.dot.gov/ISTEA

Retrieved 2016 February 14

-Kalvebod Brygge, 2010, DK Copenhagen. Rapid Urbanization and Mega Cities, page 9.

-Kunstler 1993, Duany et al. 2000. University of Memphis, with The Journal of Sustainability Education part of environment sequences.

-Lina Eklund 2012. Migration Patterns in Duhok Governorate, Iraq, 2000-2010.

-Litman.T., 2010 Impacts of Landuse onTransport: How LandUse Patterns Affect Travel
Behavior. http://www.vtpi.org/tdm/tdm20.htm. [Retrieved 201611 March];

-Mierriam Webester dictionary,

-Municipality of Duhok,2015, overview of Shandukha village (neighborhood) village.

-Renne, J. 2005. TOD-Measuring Advantages \& Analyzing Trends And Evaluating Policy.

Dissertation Submitted to Graduate Program in Urban Planning and Policy Development, Rutgers University.pdf .

-Renaissance Planning Group of Florida, 2011, Framework for TOD in Florida

-Robert Cervero and Michael Duncan, updated 2016. Using Public Transit to Create More Accessible and Livable Neighborhoods, page 19.

-Sabri, I . 2015, Statistical Office and GIS department, department of demographic changes.in Duhok city. 2015, 2016,

-Waheeda Mustafa, 2012, Uban managementand Urban Growth in Duhok, MA thesis submitted to Spatial planning-UOD, pp 2021

-UN- Habitat 2016, Urbanization and Development Emerging Futures, World Cities Report 2016.

Websites visited,

-Duhok Directorate \& planning, www.Duhokgov.org, http://www.mundhk.org/?action=5000\&lang $=3$, retrieved 201616 Oct.

-General information of Duhok, http://www.fajeralfaisal.iq/pdf/Dohuk.pdf, Retrieved 201615 Sep.

Duhok city master plan, www.google.iq/webhp?hl=ar\#hl=ar\&q=duh ok+city+master+plan Retrieved $2016 \quad 19$ Sep. 